\title{
The effectiveness of physics subject-specific pedagogy based on indigenous knowledge to improve students' patriotism
}

\author{
Tanty Dwi Purwita ${ }^{1^{*}}$, Dadan Rosana ${ }^{2}$ \\ ${ }^{1}$ Postgraduate Program of Physics Education, Universitas Negeri Yogyakarta, Yogyakarta, Indonesia \\ ${ }^{2}$ Postgraduate Program of Science Education, Universitas Negeri Yogyakarta, Yogyakarta, Indonesia \\ *Corresponding Address: tanty.purwita@gmail.com
}

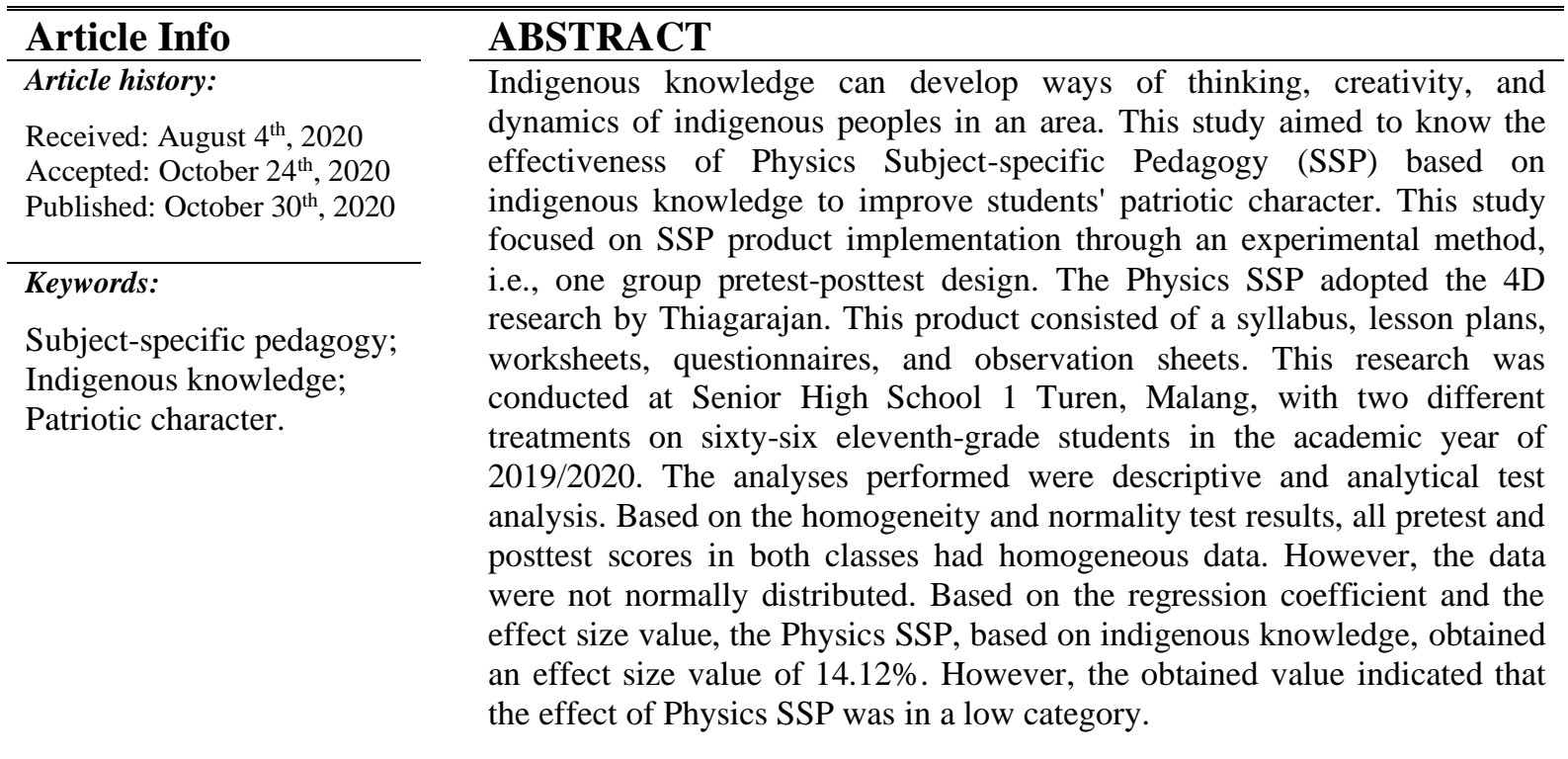

(C) 2020 Physics Education Department, UIN Raden Intan Lampung, Indonesia.

\section{INTRODUCTION}

This current era requires modernization to affect every aspect of human life (Ramadani, 2017; UNESCO, 2017). It produces heterogeneity development on the data information flows that can abridge foreign cultures' entry (Ramadani, 2017). It can slowly erode the indigenous knowledge system and lessen the love toward Indonesia as a nation and state (Ramadani, 2017; UNESCO, 2017).

In this era of modernization, moral education is needed by the young generation at an early age to cultivate many positive characters. This moral education can enrich character education (Yusoff \& Hamzah, 2015), especially love for the country and patriotic values.
Character education can imply and grasp students' ethical abilities in enhancing rational and righteous desire toward humanity (Yusoff \& Hamzah, 2015). In society, an emotional attachment and deep feeling toward the nation enables someone to help and protect the country against the enemy. Individual's sensitivity toward a nation consciously promotes sensitivity toward the world or country's problem (Bas, 2016; Göksu \& Kayalar, 2018). This kind of national-awareness character can be called a patriotic character.

Patriotism as a citizenship value is an essential component for social studies education (Jin \& Song, 2019; Öztürk et al., 2016), especially in Civic subjects. The patriotic character can be implemented in all 
learning activities (Nurdin, 2017; Ramadani, 2017; Wardhani et al., 2020). The patriotic character can be developed by linking indigenous education and local wisdom. Local wisdom comes from varied indigenous knowledge developed by interactions between communities and the environment (Khusniati et al., 2017; Rosana et al., 2019; UNESCO, 2017).

Indigenous knowledge can develop ways of thinking, creativity, and dynamics of indigenous peoples in an area. It has similarities with traditional knowledge because indigenous knowledge is developed by individual communities (EzeanyaEsiobu, 2019; Mawere, 2015; Zidny \& Eilks, 2018). Indigenous knowledge has a special meaning for the learning process because it is related to the students' daily life. Thus, enculturation learning using local culture (indigenous knowledge) can influence students' scientific thinking and character (Dewi et al., 2017; Handayani et al., 2018) because the science learned is related to the daily lives (Langtang \& Mataubenu, 2020; Parmin et al., 2017; Utami et al., 2017).

Indigenous knowledge-based learning provides useful and straightforward learning innovations to develop students' competencies in physics learning (Khusniati et al., 2017; Sukma et al., 2019). Besides, indigenous knowledge-based learning enables educators to develop self-awareness that influences their actions toward the community (Khusniati et al., 2017; Subali et al., 2015). The synergy between indigenous knowledge and science can quickly develop an innovative learning approach (UNESCO, 2017).

Several research has been carried out by integrating local wisdom with indigenous knowledge to improve problem-solving skills (Dewi et al., 2017), science literacy (Sya`ban \& Wilujeng, 2016), and various positive characters (Khusniati et al., 2017; Mannan, 2016).

One of the indigenous knowledge in Malang, East Java, is patrol music art. Patrol music as a product of cultural locality in the Bandulan area, Malang, comes from the villagers' habit of waking up people for sahoor by going around the village. At the same time, they hit a bamboo kentongan (Maftuchin, 2019). The people's habit of hitting kentongan acts as a patrol music art. This change cannot be separated from rhythm modification. This rhythm modification produces some excellent sound, and it has become the characteristic of patrol music art.

The sound of kentongan presents some aspects of physics subjects, mostly sound waves. So, this patrol music art as indigenous knowledge that can be integrated into physics subject and Subject-Specific Pedagogy (SSP).

Several previous research showed that SSP could strengthen students' abilities and their characters, for example, students' ecological literacy (Riyadi et al., 2018), problem-solving (Ubaidillah \& Wilujeng, 2019), practical skill (Rosana et al., 2019), and some good characters like honesty and care (Haryati, 2016). In this research, indigenous knowledge has been combined with the Subject-Specific Pedagogic to improve students' patriotic character.

Learning innovation in physics education can be expected to develop students' characterS. The development of Physics SSP products emphasized integrating learning activities and local wisdom assisted by student worksheets through the discovery learning model. Students can increase their discovery understanding of the concept with the teacher as a facilitator (Putra et al., 2018).

\section{METHOD}

This research was a Research and Development with the 4-D model by Thiagarajan as the development model. This research focused on the implementation of the developed Physics SSP product. This research aimed to know the effectiveness of the developed Physics SSP product to improve students' patriotic character. The 
flowchart of the research can be seen in Figure 1.

\begin{tabular}{|c|}
\hline $\begin{array}{l}\text { Development of Physics SSP Product based on } \\
\text { Indigenous Knowledge (Patrol Music) }\end{array}$ \\
\hline $\begin{array}{l}\text { Determination of the experimental method } \\
\text { with one-group pretest-posttest design. } \\
\text { This method uses } 2 \text { classes with } 33 \text { students for } \\
\text { each class as subject of research. }\end{array}$ \\
\hline $\begin{array}{l}\text { Implementation of Physics SSP Product based } \\
\text { on Indigenous Knowledge (Patrol Music) } \\
\text { - Before treatment, students were given a } \\
\text { patriotism character questionnaire } \\
\text { - During treatment, students observed the } \\
\text { patriotism character that was shown } \\
\text { - After treatment, students were given a } \\
\text { patriotism character questionnaire }\end{array}$ \\
\hline $\begin{array}{l}\text { Analysis of Students' Patriotism Character } \\
\text { - Questionnaire result analysis } \\
\text { - Non-parametric and regression analysis } \\
\text { - Observation sheets result analysis }\end{array}$ \\
\hline
\end{tabular}

Figure 1. Research's flowchart

This research had been conducted at the State Senior High School 1 Turen, Malang. The subject consisted of two eleventh-grade classes. Both classes had the same number of students. This research sample consisted of thirty-three students in each class determined through a simple random sampling technique. The experimental class had been taught using Physics SSP product based on indigenous knowledge and discovery learning. In contrast, the control class had been taught using direct learning and group presentation assignments. The treatments were performed to the same number of meetings and group division system.

The Physics SSP products consisted of a syllabus, lesson plans, student worksheets, handout, and patriotic character questionnaires. A sound wave concept was integrated into the SSP products as one of the physics sub-subjects in the eleventh grade.

This research had been conducted for three weeks (February $10^{t h}-28^{t h}, 2020$ ). Before the main research activities, some observations were carried out to determine the students' character in general.

Before implementing the Physics SSP products, the instruments involved in the research were validated by three expert lecturers and two physics teachers. The syllabus and lesson plan explain discovery learning steps based on indigenous knowledge (Patrol music art). The discovery learning was chosen because it can explain the concept of material clearly. The handout and student worksheets were accompanied by information, illustration, and drawings based on indigenous knowledge (patrol music art).

The research data had been obtained from two instruments, i.e., patriotic character questionnaires and observation sheets. The questionnaires consisted of 24 statements that have been adapted to the indicator of patriotic characters. All data collected from the pre and post questionnaires were transformed into $\mathrm{N}$-gain value (1).

$$
<G>=\frac{<X_{\text {post }}>-<X_{\text {pre }}>}{100-<X_{\text {pre }}>}
$$

Gain score $\langle G\rangle$ presents students' patriotic character before treatment $\left(X_{\text {pre }}\right)$ and after treatment $\left(X_{\text {post }}\right)$. The $\mathrm{N}$-gain results were analyzed descriptively and analytically. First, the improvement of students' patriotic character can be interpreted with $\mathrm{N}$-gain value. The $\mathrm{N}$-gain criteria can be seen in Table 2 .

Table 2. Category of n-gain score

\begin{tabular}{cc}
\hline Interval & Category \\
\hline $0.7 \leq \mathrm{G}<1$ & High \\
$0,3 \leq \mathrm{G}<0.7$ & Moderate \\
$\mathrm{G}<0.3$ & Low \\
\hline & Source: Meltzer, 2002
\end{tabular}

The data analysis process was assisted by Ms. Excel 2013 and SPSS 21.0 (descriptive test, homogeneity test, normality test, linearity test, Wilcoxon test, and simple linear regression tests).

The hypothesis stated that if the significance value was less than 0.05 , then 
the initial hypothesis $\left(H_{0}\right)$ was rejected. On the other hand, the hypothesis $\left(H_{1}\right)$ can be accepted as a conclusion. The basis for this decision was the Asymp significance value limit. Sig. (2-tailed) of 0.05 .

\section{RESULTS AND DISCUSSION}

This research's final results were Physics Subject-specific Pedagogy products integrated with indigenous knowledge from a rural area (i.e., Patrol music art). Before the implementation, the Physics SSP products had been validated by three expert lecturers. The validation results showed that the obtained mean value was 3.38 in the excellent category. Thus, the Physics SSP products were declared feasible to be implemented in the classroom. Figures 2 and 3 present the cover book of Physics SSP product and students' worksheet. Table 3 presents a description of the Physics SSP product.

Table 3. The description of physics subject-specific pedagogy based on indigenous knowledge (patrol music art)

\begin{tabular}{ll}
\hline Physics SSP products & \multicolumn{1}{c}{ Description } \\
\hline Syllabus & $\begin{array}{l}\text { It contains basic competence } 3.10 \text { and the material and activities of the sound } \\
\text { wave. It also contains indicators for the assessment of patriotic characters; }\end{array}$ \\
Lesson Plan & $\begin{array}{l}\text { The lesson plans are designed for five meetings within two hours duration. The } \\
\text { lesson plan has been integrated with patrol music art to achieve basic competency } \\
3.10 ;\end{array}$ \\
Student Worksheet & $\begin{array}{l}\text { The worksheets must be done by students in groups assisted by bamboo kentongan } \\
\text { and sound wave software; }\end{array}$ \\
& $\begin{array}{l}\text { It contains twenty-four statements given to respondents to determine their } \\
\text { perceptions or habits that reflect their patriotic characters; }\end{array}$ \\
Observation sheets & $\begin{array}{l}\text { The sheets have been adapted to patriotism to record attitudes that reflect the } \\
\text { student's patriotic characters during the learning process. }\end{array}$
\end{tabular}

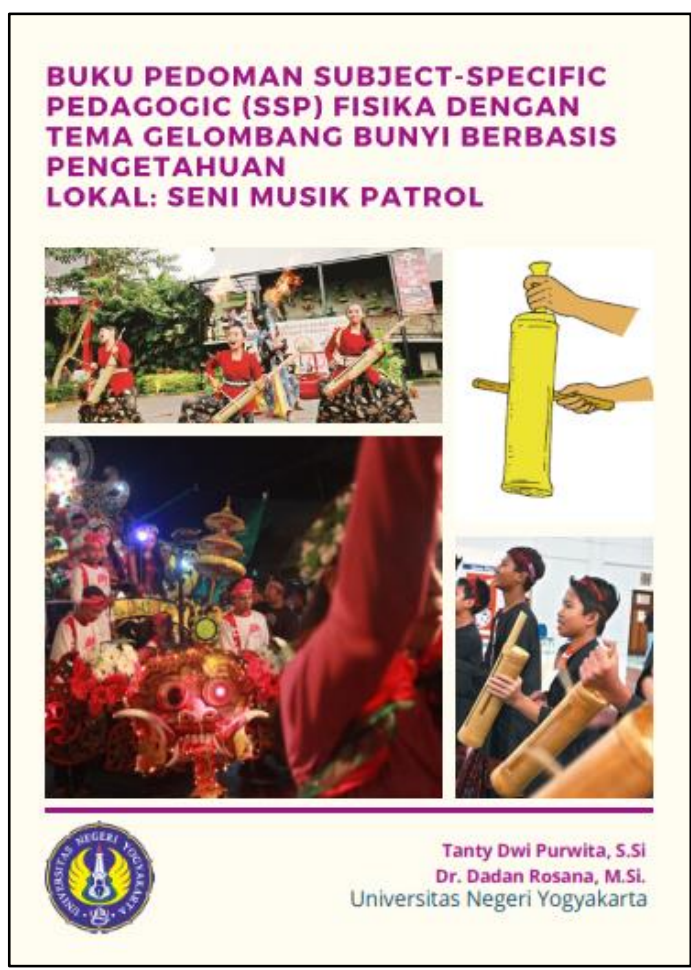

Figure 2. The cover page of physics SSP products

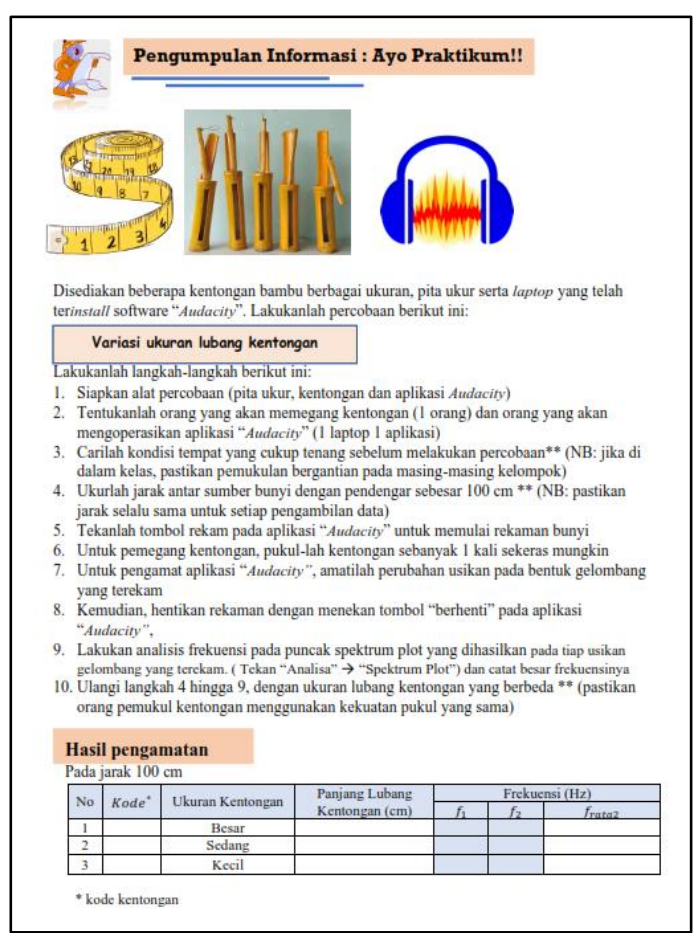

Figure 3. Patrol music-based learning activities in student worksheet 
Based on the data analysis, some information about students' patriotic characters are described as follows:

\section{The Questionnaire Analysis Result}

The questionnaire had been given to students in both classes. It contained twentyfour statements that reflected students' patriotic characters in different contexts. It employed a Likert scale with four answers; strongly agree (SA), Agree (A), disagree (D), and strongly disagree (SD). Table 4 presents the conversion of the qualitative value to quantitative value 1 .

Table 4. Conversion of values

\begin{tabular}{lcc}
\hline \multirow{2}{*}{ Answer } & \multicolumn{2}{c}{ Value Conversion } \\
\cline { 2 - 3 } & Positive & Negative \\
\hline Strongly Agree (SA) & 4 & 1 \\
Agree (A) & 3 & 2 \\
Disagree (D) & 2 & 3 \\
Strongly Disagree (SD) & 1 & 4 \\
\hline
\end{tabular}

The analysis result is shown in Figure 4 below:

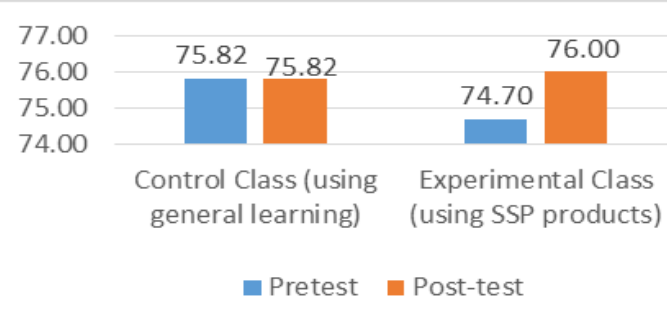

Figure 4. The pre-post questionnaire's average value

Based on Figure 4, the pre-post questionnaire's results between the two classes were similar. However, the experimental class obtained a higher posttest value than its pretest value. These average values cannot represent the role of Physics SSP in changing students' patriotic characters.

Through the results of the questionnaire before and after the treatment, the gain value had been normalized. The $\mathrm{N}$-gain value indicated a difference (change) due to different treatments. The $\mathrm{N}$-gain value can be seen in Table 5.
Table 5. The n-gain values of the experimental and control class

\begin{tabular}{llcc}
\hline \multirow{2}{*}{ Class } & \multirow{2}{*}{ N-gain } & \multicolumn{2}{c}{$\begin{array}{c}\text { Patriotic } \\
\text { Characters }\end{array}$} \\
\cline { 3 - 4 } & & Score & Category \\
\hline Experiment & Max & 0.533 & \\
al & Min & -0.330 & \\
Control & Mean & $\mathbf{0 . 0 6 1}$ & Low \\
& Max & 0.269 & \\
& Min & -0.450 & \\
& Mean & $\mathbf{- 0 . 0 1 3}$ & Low \\
\hline
\end{tabular}

Based on Table 5, the experiment class obtained a higher $\mathrm{N}$-gain value. However, both classes' $\mathrm{N}$-gain values belonged to the low category, which indicated that the treatments presented insignificant students' patriotic character changes. A more definite analysis was then continued using the SPSS application to know more about the effect of Physics SSP products on students' patriotic characters.

Before the data were analyzed with parametric/non-parametric tests, the normality and homogeneity test had been performed with the following hypothesis;

$H_{0}$ : All data are normally distributed and homogeneous

$H_{1}$ : All data are not normally distributed and homogeneous

Tables 6 and tables 7 present the normality and homogeneity test results.

Table 6. The normality test result

\begin{tabular}{lllll}
\hline \multirow{2}{*}{ Class } & \multirow{2}{*}{ Source } & \multicolumn{3}{c}{ Shapiro-Wilk } \\
\cline { 3 - 5 } Experimental & Pretest & 0.978 & 33 & $\mathbf{0 . 7 3 3}$ \\
& Post-test & $\mathbf{0 . 9 1 1}$ & $\mathbf{3 3}$ & $\mathbf{0 . 0 1 1}$ \\
Control & Pre-test & 0.970 & 33 & $\mathbf{0 . 4 7 2}$ \\
& Post-test & 0.979 & 33 & $\mathbf{0 . 7 4 2}$ \\
\hline
\end{tabular}

Table 7. The homogeneity of variance result

\begin{tabular}{ll}
\hline \multicolumn{1}{c}{ Source } & Sig. \\
\hline Pretest & 0.792 \\
Post-test & 0.446 \\
\hline
\end{tabular}

Based on Table 6, the experiment class's post-test data were not normally distributed. However, based on Table 7, all of the pretest and posttest data were homogeneous. Thus 
the test performed test was the nonparametric test, i.e., the Wilcoxon test.

\section{Wilcoxon Test}

The Wilcoxon test is a non-parametric test to determine the differences between two paired data groups. The hypothesis used as a decision making in this analysis were;

$H_{0}$ : There were no differences in two data groups between the pretest and posttest

$H_{1}$ : There were differences in two data groups between the pretest and posttest,

The results of the Wilcoxon test are presented in Tables 8 and 9.

Table 8. The outputs of the wilcoxon test

\begin{tabular}{lllc}
\hline & Rank & N & Mean Rank \\
\hline Pre-post & Negative & $26^{\mathrm{a}}$ & 24.75 \\
& Positive & $29^{\mathrm{b}}$ & 30.91 \\
& Ties & $11^{\mathrm{c}}$ & \\
& Total & 66 & \\
\hline
\end{tabular}

a. Post $<$ Pre b. Post $>$ Pre c. Post $=$ Pre

Table 8 shows that the positive difference (on the positive rank) has a more excellent value than the negative rank and the ties rank had an increased value after the treatment was given. This data analysis required more testing to test the hypothesis. Table 9 presents the difference between the pretest and posttest data on students' patriotic characters.

Table 9. Statistic output of the wilcoxon test

\begin{tabular}{lc}
\hline & Pre-Post \\
\hline$Z$ & $\mathbf{- 1 . 0 6 3}$ \\
Asymp. Sig. (2-tailed) & $\mathbf{0 . 2 8 8}$ \\
\hline a. Based on negative ranks
\end{tabular}

From Table 9, it is known that the significance value of the Wilcoxon test was more significant than 0.05 . This value means that there were no differences between the two groups' pretest and posttest scores. It also means that there was no effect of Physics SSP products on students' patriotic characters. Furthermore, the data were analyzed using the non-parametric effect size (2) (Tomczak \& Tomczak, 2014).

$$
r=\frac{Z}{\sqrt{n_{0}}}
$$

$\mathbf{Z}$ is a value result in Table 9 , and $\boldsymbol{n}_{\mathbf{0}}$ is the result of the following calculation (3) (Israel, 1992; Yamane, 1967):

$$
n_{0}=\frac{N}{1+N(e)^{2}}
$$

$\mathbf{N}$ is the population size (66 participants), and $\mathbf{e}$ is the level of precision $(0.05$ or $5 \%)$. From equations (2) and (3), the effect values obtained were 0.1412 or $14,12 \%$. The values showed an effect of Physics SSP products based on indigenous knowledge on students' patriotic characters by $14.12 \%$. According to (Cohen, 2013), the effect size value can be categorized as weak.

\section{Simple Linear Regression Test}

One way to predict one independent variable's effect on the dependent variable is the simple linear regression test. In this research, the regression test had been used to determine the effects of different treatments in both classes on the students' patriotic character.

Before performing the regression test, a linearity test needed to be done as the regression test requirement. Table 10 presents the linearity test result for both classes' N-gain data.

Table 10. The outputs of the linearity test

\begin{tabular}{lcl}
\hline $\begin{array}{l}\text { Independent*Dependent } \\
\text { variable }\end{array}$ & F & Sig. \\
\hline Treatment*Patriotism & 0.809 & $\mathbf{0 . 7 2 8}$ \\
\hline
\end{tabular}

Based on Table 10, the significance value of the linearity test was more significant than 0.05. This value showed that the overall $\mathrm{N}$-gain data had a linear correlation with the different treatments. It means that the use of Physics SSP products in the experimental class had a linear correlation with the variable's patriotic characters. The 
regression test results are shown in Table 11 .

Table 11. Simple linear regression test result

\begin{tabular}{|c|c|c|c|}
\hline \multirow[b]{2}{*}{ Model } & \multicolumn{2}{|c|}{$\begin{array}{c}\text { Unstandardized } \\
\text { Coefficient }\end{array}$} & \multirow{2}{*}{ Sig. } \\
\hline & B & $\begin{array}{l}\text { Std. } \\
\text { Error }\end{array}$ & \\
\hline (Constant) & 0.842 & 0.079 & 0.000 \\
\hline Gain Patriotism & 0.459 & 0.201 & 0.026 \\
\hline
\end{tabular}

Based on Table 11, the significance value was more significant than 0.05 . It shows no effect of the different treatments given to the two classes on students' patriotic characters.

However, when data was observed from the regression coefficient (the $\mathrm{B}$ value) in Table 11, there was a positive effect of Physics SSP products on students' patriotic characters.

Based on the Wilcoxon test, the Physics SSP products did not affect experimental class students' patriotism. The Physics SSP products had a weak effect with a value of $14,12 \%$. The patriotic character might have been caused that needs time to develop because this character must be trained through habituation.

However, based on the regression coefficient value in Table 11, the Physics SSP products produced some positive influences on the students' patriotic characters. The positive results were similar to other research (Subali et al., 2015). Subali's research (2015) indicates that local wisdom-based science learning can establish students' lively characters.

Additional information about the positive influences was obtained based on the questionnaire and observation sheets' indicators. The questionnaire analysis is presented in Table 12.

Table 12. The average value of questionnaire's patriotic character in each class

\begin{tabular}{lllll}
\hline \multirow{2}{*}{$\begin{array}{l}\text { Indicators of } \\
\text { Patriotic }\end{array}$} & \multicolumn{4}{c}{ Average Value } \\
\cline { 2 - 5 } \begin{tabular}{l} 
Characters \\
\cline { 2 - 5 }
\end{tabular} & Pre & Post & Pre & Post \\
\hline $\begin{array}{l}\text { Defending the } \\
\text { state's } \\
\text { character for } \\
\text { the motherland }\end{array}$ & 3.11 & 3.12 & 3.03 & 3.15 \\
\end{tabular}

\begin{tabular}{|c|c|c|c|c|}
\hline \multirow{3}{*}{$\begin{array}{l}\text { Indicators of } \\
\text { Patriotic } \\
\text { Characters }\end{array}$} & \multicolumn{4}{|c|}{ Average Value } \\
\hline & \multicolumn{2}{|c|}{ Ctrl Class } & \multicolumn{2}{|c|}{ Exp Class } \\
\hline & Pre & Post & Pre & Post \\
\hline Tolerance & 3.04 & 3.11 & 2.97 & 3.15 \\
\hline $\begin{array}{l}\text { Obey the } \\
\text { society's norms } \\
\text { and regulations }\end{array}$ & 3.24 & 3.26 & 3.31 & 3.31 \\
\hline Total average & 3.13 & 3.16 & 3.10 & 3.20 \\
\hline $\begin{array}{l}\text { Information: } \\
\text { Ctrl: control } \\
\text { Exp: experimental }\end{array}$ & & $\begin{array}{l}\text {-test } \\
\text { sttest }\end{array}$ & & \\
\hline
\end{tabular}

Based on Table 12, the control class's average pretest score was greater than the experimental class. However, the control class had a smaller total posttest average score than the experimental class.

Based on the average pretest and posttest scores differences, there was a positive effect of the two classes' treatments.

\section{a. The Analysis Result of Observation Sheets}

The observation sheets had been given to three observers to determine students' patriotic character during learning with or without the Physics SSP products. The observations result served as additional information about the effect of different treatments given to the two classes on students' patriotic characters. Table 13 presents the average percentage based on the three indicators of patriotic characters.

Table 13. Patriotic characters' observation sheets result

\begin{tabular}{|c|c|c|}
\hline \multirow{2}{*}{$\begin{array}{c}\text { Indicators of } \\
\text { Patriotic characters }\end{array}$} & \multicolumn{2}{|c|}{ Average value (\%) } \\
\hline & Ctrl & $\operatorname{Exp}$ \\
\hline $\begin{array}{l}\text { Defending the State's } \\
\text { Character for the } \\
\text { Motherland }\end{array}$ & 59.38 & 64.16 \\
\hline Tolerance & 61.94 & 71.95 \\
\hline $\begin{array}{l}\text { Obey the Society's } \\
\text { Norms and } \\
\text { Regulations }\end{array}$ & 67.08 & 77.08 \\
\hline Total average & 62.80 & 71.06 \\
\hline $\begin{array}{r}\text { Information: Ctrl: Con } \\
\text { Exp: Exp }\end{array}$ & $\begin{array}{l}\text { ol class } \\
\text { rimental }\end{array}$ & \\
\hline
\end{tabular}


Table 13 shows that the experimental class obtained a greater value than the control class.

Students showed their patriotic character during learning in the experimental class than the students in the control class. It might be caused by group learning activities using kentongan and software applications in explaining sound wave material. These activities were more attractive to students, and the character of patriotism can be shown unconsciously.

Using bamboo kentongan in explaining the sound wave made the students more interested during the learning process.

\section{CONCLUSION AND SUGGESTION}

The developed Physics SSP products based on indigenous knowledge positively influenced students' patriotic character. Based on the analysis results of the $\mathrm{N}$-gain value in Table 8 , both classes' $\mathrm{N}$-gain value was in a low category. Meanwhile, the Wilcoxon test results did not show any effect between the different treatments in both classes on students' patriotic characters. However, the regression coefficients and the effect size value showed positive effects of Physics SSP products on students' patriotic character with the regression coefficient of 0.459 and an effect size value of $14.12 \%$.

The diversity of indigenous knowledge from various places can be integrated with various pedagogical-content-knowledge (PCK). These pedagogic models can be adapted into various learning models. Innovative learning must involve students so that it can attract their interest during the learning process.

Also, the research took a long time because the characters must be trained through habituation. Further research can integrate other subjects with a longer duration so that the impact can be measured over a longer time.

\section{ACKNOWLEDGMENT}

The researchers would like to thank the Directorate of Research and Community
Service, the Directorate General of Higher Education, Ministry of Education and Culture, and The Institute of Research and Community Service for their financial support. Also, thank Universitas Negeri Yogyakarta for management assistance on this research project.

\section{AUTHOR CONTRIBUTIONS}

TD develop the product. DR prepared literature in accordance with research. TD and DR collected and analysed data and wrote the manuscript.

\section{REFERENCES}

Bas, M. (2016). The evaluation of the university students patriotism levels according to gender, age, family structure and sports activities. European Journal of Education Studies, 2(2), 34-43.

Cohen, J. (2013). Statistical power analysis for the behavioral sciences. In Statistical Power Analysis for the Behavioral Sciences.

Dewi, I. N., Poedjiastoeti, S., \& Prahani, B. K. (2017). ELSII learning model based local wisdom to improve students' problem solving skills and scientific communication. International Journal of Education and Research, 5(1), 107118.

Ezeanya-Esiobu, C. (2019). Africa's indigenous knowledge: From Education to Practice. Springer

Göksu, M. Z., \& Kayalar, F. (2018). Value of patriotism in the perspective of afghan students attending to secondary schools. Journal of Social and Humanities Science Research, 5(29), 3806-3817.

Handayani, R. D., Wilujeng, I., \& Prasetyo, Z. K. (2018). Elaborating indigenous knowledge in the science curriculum for the cultural sustainability. In Journal of Teacher Education for Sustainability, 20 (2), 74-88.

Haryati, S. (2016). Pengaruh SSP tematik integratif terhadap peningkatkan 
karakter kejujuran dan kepedulian siswa kelas II SD. Jurnal Prima Edukasia, 4(2), 198-208

Israel, G. D. (1992). Determining sample size fact sheet. In Determining Sample Size.

Jin, Y., \& Song, P. (2019). Exploration on implementing quality-oriented education in physics teaching in university. Atlantis Press, 322(1), 152155.

Khusniati, M., Parmin, \& Sudarmin. (2017). Local wisdom-based science learning model through reconstruction of indigenous science to improve student's conservationist character. Journal of Turkish Science Education, 14(3), 16-23

Langtang, D., \& Mataubenu, K. D. (2020). Identifying physic concepts in yarn production by none fortress society, tetaf village. JIPF (Jurnal Ilmu Pendidikan Fisika), 5(1), 31-37.

Maftuchin, A. S. (2019). Festivalization of music patrol bandulan and the quest of arek bandulan cultural identity. Journal of Indonesian Tourism and Policy Studies, 1(1), 34-42.

Mannan, M. (2016). Pengembangan perangkat pembelajaran berbasis kearifan lokal untuk mengembangkan karakter positif siswa SD. Jurnal Inovasi Dan Pembelajaran Fisika, 2(1), 141-146

Mawere, M. (2015). Indigenous knowledge and public education in Sub-Saharan Africa. Africa Spectrum.

Meltzer, D. E. (2002). The relationship between mathematics preparation and conceptual learning gains in physics: A possible-hidden variable\| in diagnostic pretest scores. American Journal of Physics, 70(12), 1259-1268.

Nurdin, E. S. (2017). Civic education policies: Their effect on university students' spirit of nationalism and patriotism. Citizenship, Social and Economics Education, 16(1), 69-82.

Öztürk, F., Malkoç, S., \& Ersoy, A. F.
(2016). Patriotism as perceived by social studies teachers: An outlook on the individual, society and education. Pamukkale University Journal of Education, 21(40), 176-190.

Parmin, Sajidan, Ashadi, Sutikno, \& Fibriana, F. (2017). Science integrated learning model to enhance the scientific work independence of student teacher in indigenous knowledge transformation. Jurnal Pendidikan IPA Indonesia, 6(2), 365-372.

Riyadi, I. P., Prayitno, B. A., \& Karyanto, P. (2018). The effectiveness of subject specific pedagogy based on problembased learning to empower student's ecological literacy. Cakrawala Pendidikan, 37(2), 212-222.

Putra, F., Nur Kholifah, I. Y., Subali, B., \& Rusilowati, A. (2018). 5E-learning cycle strategy: Increasing conceptual understanding and learning motivation. Jurnal Ilmiah Pendidikan Fisika AlBiruni, 7(2), 171-181.

Ramadani, D. (2017). The effectiveness of bung tomo's biography module based on VCT in historical learning to improve the value of patriotism. American International Journal of Social Science, 6(2), 60-65.

Rosana, D., Sukardiyono, \& Hayati, I. A. (2019). The development of SSP by utilizing nusakambangan biodiversity based on sets to enhance soft security and practical skills. International Journal of Environmental \& Science Education, 14(9), 571-581.

Subali, B., Sopyan, \& Ellianawati, A. (2015). Developing local wisdom based science learning design to establish positive character in elementary school. Jurnal Pendidikan Fisika Indonesia, 11(1), 1-7.

Sukma, T. A., Mundilarto, M., \& Putri, N. D. (2019). Local wisdom-based electronic book on newton's law. Jurnal Ilmiah Pendidikan Fisika AlBiruni, 8(2), 197-206.

Sya`ban, M. F., \& Wilujeng, I. (2016). 
Pengembangan SSP zat dan energi berbasis keunggulan lokal untuk meningkatkan literasi sains dan kepedulian lingkungan. Jurnal Inovasi Pendidikan IPA, 2(1), 66-75. https://doi.org/10.21831/jipi.v2i1.8369

Tomczak, M., \& Tomczak, E. (2014). The need to report effect size estimates revisited. An overview of some recommended measures of effect size. Trends in Sport Sciences, 1(2) 19-25.

Ubaidillah, M., \& Wilujeng, I. (2019). Developing physics SSP based on the problem solving to improve the process skills and problem-solving ability. Journal of Science Education Research, 3(1), 30-42.

UNESCO. (2017). Local knowledge, global goals. Unesco.

Utami, I. S., Septiyanto, R. F., Wibowo, F. C., \& Suryana, A. (2017). Pengembangan STEM-A (science, technology, engineering, mathematic and animation) berbasis kearifan lokal dalam pembelajaran fisika. Jurnal Ilmiah Pendidikan Fisika Al-Biruni, 6(1), 67-73.
Wardhani, A. K., . S., \& Setyowati, R. N. (2020). Implementation of model problem based learning assisted media powerpoint benefits materials unity and unity of the nation to improve the nationalism and patriotism of $\mathrm{pkn}$ in class iv sdn simomulyo III Surabaya. International Journal of Innovative Science and Research Technology, 5(7), 227-232.

Yamane, T. (1967). An introduction to statistic analysis, Second Edition. Harpers and Row.

Yusoff, M. Z. M., \& Hamzah, A. (2015). Direction of moral education teacher to enrich character education. Jurnal Ilmiah Peuradeun, 3(1), 119-132.

Zidny, R., \& Eilks, I. (2018). Indigenous knowledge as a socio-cultural context of science to promote transformative education for sustainable development: Insights into a case study on the baduy community (Indonesia) 29. Building Bridges across Disciplines for Transformative Education and a Sustainable Future, 249-255. 